\title{
The Difference in Clinical Reasoning Competence between Pre-Clinical Students and Clinical Students on Pediatric Tropical Disease Cases
}

\author{
Pujiati $^{1^{*}}$ \\ 1 Pediatrics Departement of Medical Faculty of Sultan Agung Islamic University \\ * Email: pujiatiabbas@gmail.com
}

\begin{abstract}
ABSTRAK
Pendahuluan: Penalaran klinik merupakan proses berpikir yang terjadi ketika berbagai informasi yang diperoleh melalui kasus klinik yang diberikan atau ditemui oleh mahasiswa kedokteran, kemudian diolah dan dipergunakan untuk mendiagnosis dan menatalaksana masalah pasien. Pengalaman dan perolehan materi merupakan faktor penting yang berpengaruh terhadap penalaran klinik. Berbagai teori menjelaskan bahwa mahasiswa pada jenjang pendidikan kedokteran preklinik dan klinik masih dalam tahapan novice sehingga kemungkinan memiliki kemampuan penalaran klinik yang sama. Di sisi lain, telah dilaporkan, terdapat perbedaan kemampuan penalaran klinik pada tingkatan akademik yang berbeda. Tujuan: mengetahui perbedaan kemampuan penalaran klinik pada mahasiswa preklinik dengan mahasiswa klinik. Metode: dalam penelitian observasional dengan rancangan cross sectional. Sebanyak 120 mahasiswa FK UNISSULA yang terdiri dari 60 mahasiswa preklinik angkatan 2011 yang telah mengikuti modul penyakit tropis dan 60 mahasiswa rotasi klinik stase ilmu kesehatan anak untuk menjawab menjawab 20 butir soal dalam bentuk Script Concordance Test (SCT) kasus penyakit tropis anak. Soal SCT disusun oleh spesialis anak, direview struktur dan konten oleh ahli pendidikan kedokteran, serta dikonkordansi oleh 10 ahli bagian anak. Perbedaan nilai SCT ke dua kelompok diuji statistik dengan Mann Whitney U menggunakan software SPSS 16 , dengan tingkat kesalahan diterima jika $p<0.05$.

Hasil: Hasil uji non parametrik dengan menggunakan Mann-Whitney menunjukkan bahwa rerata nilai SCT pada kelompok preklinik lebih rendah $(8,57 ; \pm 1,81)$ dibanding rerata nilai kelompok mahasiswa klinik $11,49( \pm 1,98) p=0,000$.

Kesimpulan: kemampuan penalaran klinik yang diukur dengan SCT pada mahasiswa klinik lebih tinggi daripada mahasiswa klinik.
\end{abstract}

Kata kunci: kemampuan penalaran klinik, script concordance test (SCT), mahasiswa preklinik, mahasiswa rotasi klinik

\section{ABSTRACT}

Introduction: Clinical reasoning is a thinking process happened when various informations gathered from clinical cases were given or met by medical students, and used for formulating diagnosis and solving patients problems. Experiences and material inputs are important factors affecting clinical reasoning. Various theories explained that students on pre-clinical and clinical rotation level are still on the novice stage, so it is possible to have similar stage on clinical reasoning. On the other hand, it was reported that there are differences in clinical reasoning on different academic stages. Objective: knowing the differences of clinical reasoning on preclinical students and clinical students. Method: observational study with cross sectional design. Respondents of this study were 120 students from medicine faculty of Sultan Agung Semarang University, comprised of: 60 preclinical students whom have been underwent tropical disease modul batch 2011 and 60 clinical rotation students on pediatric stage. Respondents answered 20 items questions in Script Concordance Test (SCT) form on pediatric tropical disease cases. SCT items were prepared by pediatricians, structures and contents were reviewed by medical education experts and concordanced by 10 experts of pediatric unit. Value differences between 2 groups were statistically analyzed using Mann Whitney U on SPSS 16.0, with acceptable error accepted level if $p<0.05$.

Result: non parametric result test by Mann-whitney showed that mean score of SCT on preclinical group were lower $(8,57 ; \pm 1,81)$ than on clinical rotation students $11,49( \pm 1,98) p=0,000$.

Conclusion: clinical reasoning competence measured by SCT is higher on clinical rotation students compared to pre clinical students.

Keywords: clinical reasoning competency, script concordance test (SCT), pre clinical students, clinical rotation students

\section{INTRODUCTION}

Indonesian Doctors' Standard Competencies year 2012 published by Indonesian Medical Council stated that general practitioner must have dengue fever treatment skill to level 4A. As consequence, a doctor must be able to make clinical diagnosis and treat illness independently and comprehensively treatment (Indonesian Medical Council, 2012). To meet
Indonesian doctors' Standard Competencies, clinical reasoning skills to make diagnosis and choose the right treatments for the patients become one of the most important skills for a doctor to have, apart from physical and complimentary examination skills treatment.

Clinical reasoning is a cognitive process which occurs when various informations gathered from anamnesis and physical examination or through clinical

Copyright @ 2015 Authors. This is an open access article distributed under the terms of the Creative Commons Attribution-NonCommercialShareAlike 4.0 International License (http://creativecommons.org/licenses/by-nc-sa/4.0/), which permits unrestricted non-commercial use, distribution, and reproduction in any medium, provided the original author and source are properly cited. 


\section{Pujiati}

cases given to medical students, were then synthesized and integrated with prior knowledge and experiences to diagnose and treat patients problems (Groves et al., 2002). Every actions conducted by medical students to learn clinical skills such as diagnosing, choosing a therapy or making prognosis are the result of understanding process of the medical problems phenomena. During the understanding process, the vital part needed arehow to think logically and critically. These were because there are several factors to be considered prior making clinical decision. Clinical experience can be one factor to differentiate clinical reasoning competency between pre clinical students and clinical students. Furthermore, the markings obtained when pre clinical stage was possibly effecting those competency. However, Cuthbert et al (1999) explained that both preclinical and clinical students are still in the same group, which is novice, so it is possible to have the relatively similar clinical reasoning competency On the contrary, clinical reasoning skills and the ability to solve medical problems are very dependent onstudents's ability to organize gained knowledge (Schuwirth, 2009). Therefore the level of education and knowledge can effect clinical reasoning. Study by Humbert (2011) supported that statement and reported the difference of clinical reasoning scores which are measured by script concordance test for year 2 and year 4 students. Further research are needed to find out the difference between clinical reasoning competency for different levels of medical students such as pre clinical level and clinical http://jurnal.unissula.ac.id/index.php/sainsmedika

level to answer the difference of opinions.

One of the instrument used to measure clinical reasoning skill is Script Concordance Test (SCT). There are various research stating that the instrument is valid and reliable (Humbert et al., 2011; Charlin et al., 2000; Brailovsky et al., 2001). Reliability of the items can be accepted if the concordance is conducted by at least 10 expert during SCT panel.

\section{METHOD}

This observational analitic study with cross sectional design which involving, 120 medical students from medicine faculty of sultan agung Islamic university. Respondents were divided in 2 groups. Each group consisted of 60 pre clinical students batch 2011 and 60 clinical rotation students who fulfill the inclusion criteria: preclinical students who passed tropical disease module, clinical students who already passed pediatric ward and never repeat the stage, willing to participate, presence during data collection and experience PBL curriculum.

From 240 students batch 2011, 90 were excluded because of failure on tropical diseases modules, and only 80 students could attended SCT. Furthermore, numbering and random sampling were administered until the number of sample are 60 students. Whilst for clinical students, 62 respondents was gathered by total sampling. Two students were excluded because repeating pediatric stage. In the end, the total data was obtained from 120 respondents, 60 pre clinic students

Table 1. Blue print assessment SCT items on pediatric tropical diseases cases

\begin{tabular}{cllll}
\hline $\begin{array}{c}\text { item } \\
\text { number }\end{array}$ & \multicolumn{1}{c}{ Topic } & Competency & \multicolumn{1}{c}{ Type } & Bloom \\
\hline 1 & Morbili & $4 \mathrm{~A}$ & Pathophysiology & C4 \\
2 & Morbili & $4 \mathrm{~A}$ & Treatment & C5 \\
3 & Varicella & $4 \mathrm{~A}$ & Pathophysiology & C4 \\
4 & Varicella & $4 \mathrm{~A}$ & Treatment & C3 \\
5 & Dengue & $4 \mathrm{~A}$ & Treatment & C5 \\
6 & Dengue & $4 \mathrm{~A}$ & Treatment & C3 \\
7 & Dengue & $4 \mathrm{~A}$ & Pathophysiology & C4 \\
8 & Parotitis epidemica & $4 \mathrm{~A}$ & Pathophysiology & C4 \\
9 & Malaria & $4 \mathrm{~A}$ & Patofifiologi & C4 \\
10 & Malaria & $4 \mathrm{~A}$ & Treatment & C3 \\
11 & Malaria & $4 \mathrm{~A}$ & Treatment & C5 \\
12 & Pertusis & $4 \mathrm{~A}$ & Pathophysiology & C4 \\
13 & Pertusis & $4 \mathrm{~A}$ & Treatment & C3 \\
14 & Tetanus & $4 \mathrm{~A}$ & Pathophysiology & C4 \\
15 & Tuberculosis & $4 \mathrm{~A}$ & Treatment & C3 \\
16 & Tuberculosis & $4 \mathrm{~A}$ & Pathophysiology & C4 \\
17 & Typhoid & $4 \mathrm{~A}$ & Pathophysiology & C4 \\
18 & Typhoid & $4 \mathrm{~A}$ & Treatment & C5 \\
19 & Ancylostomiasis & $4 \mathrm{~A}$ & Pathophysiology & C4 \\
20 & Ancylostomiasis & $4 \mathrm{~A}$ & Treatment & C3 \\
\hline
\end{tabular}


http://jurnal.unissula.ac.id/index.php/sainsmedika

The Difference of Clinical Reasoning Competence between Pre-Clinical Students and Clinical ...

Table 2. SCT concordance result by 10 pediatrician

\begin{tabular}{|c|c|c|c|c|c|c|c|c|c|c|c|}
\hline \multirow{2}{*}{$\begin{array}{l}\text { pediatrician } \\
\text { SCT Items }\end{array}$} & $\mathbf{A}$ & $\mathbf{B}$ & $\mathbf{C}$ & $\mathbf{D}$ & $\mathbf{E}$ & $\mathbf{F}$ & G & $\mathbf{H}$ & I & $\mathbf{J}$ & \multirow{2}{*}{ Answer weight } \\
\hline & \multicolumn{10}{|c|}{ Answer } & \\
\hline 1 & 4 & 4 & 4 & 4 & 4 & 4 & 4 & 4 & 3 & 4 & $4=90 \%, 3=10 \%, 2=0,1=0$ \\
\hline 2 & 2 & 2 & 4 & 2 & 2 & 2 & 3 & 4 & 2 & 4 & $4=30 \%, 3=10 \%, 2=60 \%, 1=0$ \\
\hline 3 & 2 & 2 & 4 & 4 & 4 & 4 & 3 & 2 & 2 & 4 & $4=50 \%, 3=10 \%, 2=40 \%, 1=0$ \\
\hline 4 & 2 & 2 & 2 & 4 & 2 & 2 & 4 & 2 & 4 & 2 & $4=30 \%, 3=0,2=70 \%, 1=0$ \\
\hline 5 & 2 & 2 & 4 & 4 & 4 & 4 & 4 & 4 & 4 & 4 & $4=80 \%, 3=0,2=20 \%, 1=0$ \\
\hline 6 & 4 & 4 & 4 & 4 & 4 & 4 & 4 & 2 & 4 & 4 & $4=90 \%, 3=0,2=10 \%, 1=0$ \\
\hline 7 & 4 & 4 & 2 & 4 & 4 & 4 & 4 & 2 & 4 & 2 & $4=70 \%, 3=0,2=30 \%, 1=0$ \\
\hline 8 & 4 & 4 & 4 & 4 & 4 & 4 & 4 & 4 & 4 & 4 & $4=100 \%, 3=0,2=0,1=0$ \\
\hline 9 & 4 & 4 & 2 & 4 & 4 & 4 & 4 & 4 & 4 & 4 & $4=90 \%, 3=0,2=10 \%, 1=0$ \\
\hline 10 & 2 & 2 & 2 & 4 & 4 & 2 & 2 & 2 & 2 & 2 & $4=20 \%, 3=0,2=80 \%, 1=0$ \\
\hline 11 & 1 & 1 & 4 & 4 & 4 & 4 & 4 & 2 & 1 & 4 & $4=50 \%, 3=0,2=10 \%, 1=30 \%$ \\
\hline 12 & 4 & 4 & 4 & 4 & 4 & 4 & 4 & 4 & 4 & 4 & $4=100 \%, 3=0,2=0,1=0$ \\
\hline 13 & 2 & 2 & 4 & 4 & 2 & 4 & 2 & 2 & 2 & 3 & $4=30 \%, 3=10 \%, 2=60 \%, 1=0$ \\
\hline 14 & 4 & 4 & 4 & 4 & 4 & 4 & 4 & 4 & 4 & 4 & $4=100 \%, 3=0,2=0,1=0$ \\
\hline 15 & 1 & 1 & 3 & 3 & 3 & 2 & 1 & 2 & 3 & 2 & $4=0,3=40 \%, 2=30 \%, 1=30 \%$ \\
\hline 16 & 4 & 4 & 4 & 4 & 4 & 4 & 4 & 4 & 4 & 4 & $4=100 \%, 3=0,2=0,1=0$ \\
\hline 17 & 4 & 4 & 4 & 4 & 4 & 4 & 4 & 4 & 4 & 4 & $4=100 \%, 3=0,2=0,1=0$ \\
\hline 18 & 2 & 2 & 2 & 4 & 2 & 2 & 4 & 2 & 2 & 4 & $4=30 \%, 3=0,2=70 \%, 1=0$ \\
\hline 19 & 2 & 2 & 4 & 2 & 4 & 4 & 2 & 4 & 4 & 1 & $4=50 \%, 3=0,2=40 \%, 1=10 \%$ \\
\hline 20 & 2 & 2 & 2 & 2 & 2 & 2 & 2 & 2 & 2 & 4 & $4=10 \%, 3=0,2=90 \%, 1=0$ \\
\hline
\end{tabular}

respondents and 60 clinical students respondents.

SCT items arrangement were conducted by pediatrician, begin with items selection pediatric tropical diseases with blueprint as follows, illustrated on table 1.

The SCT items arranged were then structured review by medical education expert. Item corrections were done based on reviewers inputs. Final reviewed and revised items were then tested to the students and to 10 pediatrician for the concordance process.

SCT concordance result by 10 specialists were illustrated on table 2 .

Respondents were informed how to use the SCT and some practice examples was also given before the test. After all subjects understand about the rules to answer the SCT item, they did the SCT items prepared by the researchers.

Validity and reliability of SCT items were conducted using factorial analysis, and resulted KaiserMeyer-Olkin Measure of Sampling Adequacy (KMO) $0,647(>50 \%)$ extraction result with mean score of
$>0,4$, indicated that SCT items is adequate to use in this study. Reliability test resulted cronbach alpha score of $0,755(>0,6)$ indicated SCT items's reliability.

SCT score collected from preclinical and clinical students are tested for normality and homogenity. Normality test by Kolmogorov Smirnov for preclinical group were $p=0,01$, which meant data was not normally distributed, and for clinical students were $p=0,200$, which indicated that the data is normally distributed. Data was homogenized, proven by homogenity test was $p=0,987(>0,05)$. Considering SCT score of preclinical students was not normally distributed, non parametric test by Mann Whitney was conducted to find out the difference between two groups. SPSS 16.0 software was used, with acceptable error level if $p<0.05$.

All respondents signed informed consent as research participants. The result were informed to them and their names are kept confidential. Ethical clearance was obtained from Ethical committee of Faculty of Medicine Sultan Agung Islamic University. 


\section{Pujiati}

Table 3. SCT mean score of preclinical and clinical students

\begin{tabular}{lcc}
\hline Academic Stage & Mean & P \\
\hline Pre Clinical & $8,57 \pm 1,81$ & $0.000^{*}$ \\
Clinical & $11,49 \pm 1,98$ & \\
\hline
\end{tabular}

* Significantly different based on Mann Whitney U test

\section{RESULT}

Statistical analysis using Mann Whitney $U$ showed that mean score of SCT for clinical students are significantly higher than preclinical students $P=0.000$, were illustrated on table 3 .

Non parametric test score by Mann Whitney $U$ was $p=0,000$, which indicates that there is significant difference. This finding described that clinical reasoning for clinical students were better than preclinical students.

\section{DISCUSSION}

This study's result showed that clinical reasoning for clinical students group is higher than preclinical students. Contradicted to Cuthbert et al (1999), which explained that preclinical and clinical students are both on the same novice level and have the same clinical reasoning competence. Both groups were assumed having the same knowledge level because all respondents have passed tropical diseases module. Having experienced with patients were thought play role on clinical reasoning development of clinical students. Irfannudin (2009) reported clinical reasoning ability, measured by SCT, from clinical students were better than pre-clinical students. Similar to previous study which used DTI (Diagnostic Thinking Inventory), reported that there are differences in clinical reasoning for medical students from different academic years (Gandes,2008). The research were using 41 items on DTI which was designed to measure the competence of 2 aspects of diagnostic thinking: 1). flexibility in thinking level (20 items) and 2). to measure how far a person organizing knowledge into memory (21 items). Apart from that, Irfannudin (2009) by using SCT with total 60 items reported that students from higher batch have better clinical reasoning competency from the students from lower batch. It was explained that knowledge, cognition ability and experience also effecting students' thinking processes (Charlin, dkk., 2006). Knowledge development and clinical experience are process which complete each other so each experience was interpreted based on gained knowledge or experience to revise previous knowledge. Clinical ecperience inductively will emerge clinical reasoning but it is not enough to make clinical consideration. Critical thinking process based on gained knowledge must be inline with clinical experience on making clinical consideration. (Osman, 2005).

Clinical reasoning for clinical students were influenced by direct learning experience from patients. Groves et al., (2002) referring to Newble, explained that clinical reasoning was cognitive process occured when various informations obtained from anamnesis and physical examination or from clinical cases given to medical students synthesized and integrated with knowledge and experience previously earned by doctors and students which then used to diagnose and treat patients' problems. During clinical education program, each students are facing directly with patients who encourage them to gather clinical information process, making diagnosis and treat patients problemstreatment. Those whole process gave the opportunity for students to develop clinical reasoning. Meanwhile during learning activity, preclinical students were not yet experienced to real patients because during pre clinical learning they just experienced patients simulations on OSCE (Objective Structured Comprehensive Examination). Furthermore, to accomplish various clinical cases, preclinical students also receive cases scenario as trigger for problem based learning discussion.

Various research explained the precise diagnosis from clinicians are based on mastery of knowledge. Ability to organize knowledge is very influential to make clinical decision not as many information a person can have (Schuwirth, 2009). Clinical reasoning require good knowledge organization consisting scientific and professional theories, procedural techniques and personal philosophy strategies, values and ethics. Study by Jensen on paramedics indicated that clinical reasoning has important role to determine clinical decision. Because of that, medical professionals are expected to have basic and multidimensional knowledge which can be obtained from professional education and reflective practices to respect patients and colleagues as learning resources (Jensen, 2000). During clinical clerkship students can have better metacognition which is commonly used and increased from cases reflections to the direct patient contacts. Those experiences are making them possible to have better clinical reasoning than preclinical students. 
http://jurnal.unissula.ac.id/index.php/sainsmedika

The Difference of Clinical Reasoning Competence between Pre-Clinical Students and Clinical ...

Clinical reasoning is very important in diagnosis process (Schuwirth, 2009). The more students are exposed to clinical reasoning activities into several cases, the better diagnosing skills, and overcoming patients's problem more comprehensively. Medical Education institution must guarantee that each student is capable to develop clinical reasoning skills gradually to become a qualified doctor. Sufficient process and learning experience can build the competence because success in their final exam (one spot examination) are not representing whether a student already have sufficient clinical experience. (Martin, 2000).

Overall, the result of this research is different with the statement that said that all medical students are novice so they have similar clinical reasoning competence (Cuthbert et al., 1999) This research illustrated that experience and ability to organize gained knowledge during clinical education as contributing factor for students ability to analyze and solving patients' problem.

\section{CONCLUSION}

Clinical students have better clinical reasoning compared to preclinical students measured by script concordance test. Refering to this study, pre clinical students should be experieced to cases so they will have better clinical reasoning.

\section{REFERENCES}

Brailovsky C, Charlin B, Beausoleil S, ,1., 2001. Measurement of clinical reflective capacity early in training as a predictor of clinical reasoning performance at the end of residency: an experimental study on the script concordance test. Medical Education; 35:430436

Charlin,B, Brailovsky C, Roy L, 2000. The Script Concordance Test: A Tool to Assess the Reflective Clinician. Teach Learn Med; 12(4),189-195

Charlin B, Gagnon R, Pelletier J,2006. Assessment of clinical reasoning in the context of uncertainty: the effect of variability within the reference panel. Medical Education; 40:848-854. doi:10.1111/ j.1365-2929.2006.02541.x

Cuthbert.L.1999. Expert/Novice differences in Diagnostic Medical Cognition-A Review of the Literature. Cognitive Science Research Paper.University of Sussex.1999
Duggan, P.2007. Development of a Script Concordance Test using an Electronic Voting System, ergo, 2007. vol.1,no.1,pp.35-41

Gandes R, Mc Aleer S (2008). Clinical reasoning of Indonesian medical students as measured by diagnostic thinking inventory. South East Asian Journal of Medical Education.vol.2,no.1.

Groves, M, Scott, I, Alexander, H.2002. Assessing clinical reasoning: a method to monitor its development in a PBL curriculum, Medical Teacher,vol 24, No.5.507-515

Humbert, A, 1. 2011. Assessment of clinical reasoning: A Script Concordance test designed for pre-clinical medical students, Medical Teacher; 33:472-477

Irfannudin.(2009). Knowledge and critical thinking skills increase clinical reasoning ability in urogenital disorders: a Universitas Sriwijaya Medical Faculty experience.Vol.18,No.I

Jensen, G.M., Gwyer,J., Shepard,K.F., \&Hack,L. M.(2000). Expert practice in physical therapy. Physical Therapy,80(1), 28-43

Konsil Kedokteran Indonesia. 2012. Standar kompetensi dokter Indonesia 2012. http://inamc.or.id/ download/Standar\%20Kompetensi\%20Dokte r.pdf accesed on 5 mei 2013. Semarang

Martin I G, Stark P, Jolly B. 2000. Benefiting from clinical experience: the influence of learning style and clinical experience on performance in undergraduate objective structure clinical examination. Medical Education; 34:530-4

Osman H. 2005. Critical thinking in nursing practice. King Faisal Specialist Hospital and Research Center.

Schuwirth,L. 2009. Is assessment of clinical reasoning still the Holy Grail?. Medical Education; 2009; 43:298-299 